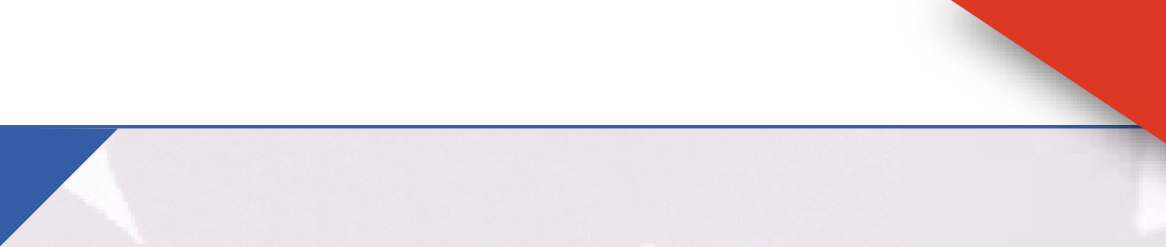

$$
\begin{gathered}
\text { The } \\
\text { Mooues } \\
\text { netter }
\end{gathered}
$$

November 2002 


\section{The Rhodes Cook Letter}

NOVEMBER 2002 / VOL. 3, NO. 5

Contents

Fit to be Tied: The Battle to Control Congress in 2002 .. 3

Chart: The Evolution of a Tie . . . . . . . . . . . . . . . . . . . . . 4

Chart: A Popular President, His Party Benefits. . . . . . . . . . . . . . . 5

Chart: Vox Populi ..................................... 6

Chart: House Reapportionment: The Top Three States Each Decade . . . . . . . 7

\section{Current Developments, Current Trends}

Chart: The Changing Composition of the 107th Congress.............8 8 Map \& Chart: 'Big Ticket' Races: Republican Victories in the Last 10 Elections 9

Chart: Longest Current Winning Streaks in Gubernatorial and Senate Races 11

\section{The 2002 Congressional Elections}

\section{Do the Math, and the Result Is: Not Much of a Contest. 12}

Chart: Competitive House Races Since 1990 . . . . . . . . . . . . . . . . . 12

Chart: Paired Incumbents: They Could Prove Decisive. . . . . . . . . . . . . 14

Chart: House Marginals. . . . . . . . . . . . . . . . . . . . . . . . . . . 15

Chart: The Iraq Vote and the 2002 Senate Lineup . . . . . . . . . . . . . . 17

The Battle for the Senate: A Strange Finish . . . . . . . . . . . . . . . . . . 18

\section{The Best of the Rest}

Chart: Third Party/Independent Governors Since 1990 . . . . . . . . . . . 19

Chart: Third Party/Independent Candidates of Note in 2000 . . . . . . . . . 19

\section{Election Day Lineups}

Chart: 2002 Gubernatorial \& Senate Candidates at a Glance . . . . . . . . . 20

Chart: Election Day Poll Closing Times . . . . . . . . . . . . . . . . . . . 21

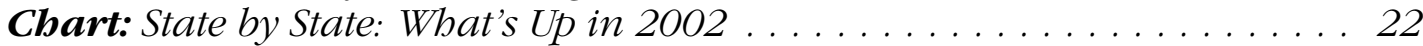

\section{Subscription Page ..................... 23}

The Rhodes Cook Letter is published by

Rhodes Cook. Web: rhodescook.com. E-mail: rbodes@rbodescook.com. Design by Landslide Design, Rockville, MD. "The Rhodes Cook Letter" is being published on a bimonthly basis in 2002.
A subscription for six issues is \$99. Make checks payable to "The Rhodes Cook Letter" and send them, along with your e-mail address, to P.O. Box 574, Annandale, VA. 22003. See the last page of this newsletter for a subscription form.

All contents are copyrighted (c2002 Rhodes Cook. Use of the material is welcome with attribution, though the author retains full copyright over the material contained herein. 


\title{
Fit to be Tied:
}

\section{The Battle to Control Congress in 2002}

\author{
By Rhodes Cook
}

\begin{abstract}
As originally published in the November/December 2002 issue of Public Perspective.
\end{abstract}
ne of the working assumptions about this year's midterm elections is that whatever changes take place on Capitol Hill will be incremental in number. But even if that turns out to be the case, the 2002 congressional elections will be much more than a pit stop between presidential campaigns.

When the partisan balance is as close as it is now - a Republican majority of five seats in the House, a Democratic edge of one seat in the Senate - it does not take much of a change to have major ramifications.

And there are significant forces at play this year that could alter the composition of Congress not just by a little, but by a lot - a result that might push one party, or the other, into clear control on Capitol Hill and possibly move the nation into a new political era.

For much of the 20th century, change in Washington's partisan dynamic moved at a plodding pace. For most of the first third of the century, the Republicans controlled both the White House and Congress. For most of the second third, the Democrats controlled both ends of Pennsylvania Avenue. And for the quarter century that followed, from 1969 through 1992, the nation's capital frequently boasted "divided government," with a Republican president and a Democratic Congress.

Yet the back and forth of national politics has accelerated over the last decade, with neither party able to gain a firm grip on either the White House or Congress. The result, since 1992, has been five different combinations running the federal government: a Republican president (George Bush) and a Democratic Congress; a Democratic president (Bill Clinton) and a Democratic Congress; a Democratic president (Clinton) and a Republican Congress; a Republican president (George W. Bush) and a Republican Congress; and most recently, a Republican president, a Republican House and a Democratic Senate.

In short, the virtual tie that exists now has been building over the last decade, to the point that if one adds together the nationwide House vote for the five elections conducted since the last round of congressional redistricting in 1992, the result is a virtual dead heat. A total of 203.9 million votes were cast for Republican House candidates and 202.5 million votes for Democrats, resulting in a GOP plurality of just 1.4 million votes out of more than 400 million cast in national elections from 1992 through 2000.

But if the last decade tells us anything, it is that the political dynamic is always in motion, always changing. And each party has some significant advantages this fall as they seek to break the partisan balance on Capitol Hill in their favor.

\section{Does Presidential Popularity Trump History?}

\section{A $\mathrm{n}$ arrow in the Democrats' quiver is the simple matter of history. The president's party in Congress almost always loses ground in midterm elections, an average of 25 seats in the}


House and four seats in the Senate in midterm voting since the end of World War II.

If the focus is only on postwar Republican presidents at their first midterm - Dwight D. Eisenhower in 1954 , Richard

Nixon in 1970 , Ronald Reagan in 1982, and George Bush in 1990 - the average GOP loss is reduced to 16 seats in the House and none in the Senate. Yet even a replication of those numbers this fall would not be good enough for congressional Republicans to either hold the House or regain the Senate.

Still, it is an open question how much history still applies in midterm elections. In the last such vote in 1998, when President Clinton's impending impeachment was the focus

\section{The Evolution of a Tie}

Since 1990, the Democrats have controlled Congress for a few years, followed by the Republicans for a few years. Since mid-2001, Democrats have run the Senate and Republicans the House of Representatives. What's next?

\begin{tabular}{ccccc|cccc} 
& \multicolumn{9}{c}{ Senate } \\
\cline { 2 - 8 } Election & Dems. & Reps & Other & Plurality & Dems & Reps & Other & Plurality \\
\hline 1990 & 56 & 44 & 0 & D 12 & 267 & 167 & 1 & D 100 \\
1992 & 57 & 43 & 0 & D 14 & 258 & 176 & 1 & D 82 \\
1994 & 47 & 53 & 0 & R 6 & 204 & 230 & 1 & R 26 \\
1996 & 45 & 55 & 0 & R 10 & 207 & 227 & 1 & R 20 \\
1998 & 45 & 55 & 0 & R 10 & 211 & 223 & 1 & R 12 \\
2000 & 50 & 50 & 0 & R 0 & 212 & 221 & 2 & R 9 \\
2002 & 49 & 49 & 1 & & 211 & 223 & 1 & R 12 \\
(Oct.) & & & & & & & &
\end{tabular}

Note: With Republican Vice President Dick Cheney available to cast tie-breaking votes, Republicans had control of the Senate after the 2000 election. Control shifted to the Democrats in June 2001 when Republican Sen. Jim Jeffords became an independent. Totals reflect the results of each election with the exception of October 2002 figures. They include three Democratic House vacancies in the Democratic total. However, the Democratic vacancy in the Senate is not counted in the Democratic total since the seat can be filled at any time by appointment.

Source: Vital Statistics on Congress 1999-2000. of attention, Demo-

crats actually gained five seats in the House and held their ground in the Senate. It marked the first time since the New Deal election of 1934 that the president's party had not lost House seats in midterm voting, and was only the fourth time since 1934 that the president's party had not lost Senate seats in a midterm election.

Clinton's name was not on the ballot in 1998. But ironically, throughout the year the beleaguered president enjoyed some of the highest presidential approval numbers of his administration. On the eve of the 1998 balloting, the Gallup Poll registered two-thirds of Americans approving his presidency (if not his personal behavior). And by and large, the higher a president's approval numbers, the better his party's showing in the midterm voting.

This year, Bush's high approval ratings should be an asset to congressional Republicans. He began the year at 84 percent in the Gallup Poll, the highest opening mark for any president in a midterm election since Franklin D. Roosevelt in 1942. Although Bush's popularity slipped a little throughout the spring and summer, it has remained high. And regardless of where he stands in the eyes of the voters come Election Day, he has already proved a mighty boon for Republicans at the cash register, raising tens of millions of dollars for GOP candidates.

\section{Reading the Terrain}

ne of the most compelling questions to be answered by this November's vote is whether the unusual strength shown by the president's party in 1998 is an aberration or the new 
norm for midterm elections.

Certainly, it seems, congressional politics has been in a "dead ball" era. Gone is the old quality of ebb and flow, with scores of House members pulled into office on the coattails of a popular president, only to be defeated in the succeeding midterm election when he is not on the ballot.

What ebb and flow there has been in recent elections has had a nickel and dime quality to it, with the conspicuous exception of the political tsunami in 1994 that swept the Republicans into power on both sides of Capitol Hill. With easy targets on the decline and the cost of campaigns on the rise, the parties hotly contest fewer and fewer districts.

That is the case again this year, although redistricting adds an element of unpredictability to the House elections. Except in the seven states with a single representative, all House members must run this fall in districts that have been at least slightly altered to reflect population changes over the last decade.

That roils the normally settled waters at least a bit for House incumbents and could put a few more at risk than would normally be the case. In each of the last two decades, more incumbents were defeated in the post-redistricting years (1982 and 1992) than in any other election in those decades (combining primary and general election defeats).

If there is similar volatility this year, either party could emerge as the prime beneficiary. In 1982, the "out" party (the Democrats) gained House seats. In 1992, it was the president's party (the Republicans) that gained seats.

On the Senate side, the conventional wisdom this year is that the terrain favors the Republicans. The GOP has more seats to defend - 20 to the Democrats' 14. But 23 of the 34 seats will be contested in states won by Bush in 2000, only 11 in states won by Democratic nominee Al Gore. 
Yet the correlation between Senate and presidential voting is far from perfect. Two loyally Republican states at the presidential level, North and South Dakota, have four Democratic senators between them, led by Senate Majority Leader Tom Daschle of South Dakota. Meanwhile, Maine and Pennsylvania, which voted twice for Clinton and once for Gore, each have a pair of Republican senators.

Altogether, more than two-thirds of the Senate seats that switched party hands in the last three midterm elections (11 of 15) were in states that were carried by the other party's presidential candidate in the previous election. That includes six seats the Republicans picked up in 1994 in states that had been won by Clinton two years earlier. Without those half dozen seats, Republicans would not have won a Senate majority in 1994.

\section{Issues and Turnout}

\section{n十}

he outcome of the 2002 elections will be heavily influenced by whether either party can win _ the "issues" debate. Democrats are expected to run best if the spotlight is on domestic issues, from the fate of Social Security and prescription drug benefits to corporate wrongdoing and the nation's struggling economy.

In the last quarter century, the two biggest Democratic years came when Republican administrations were thrown on the defensive by the perception of recession. In 1982, the Democrats gained 26 House seats, the most for the party in any election since the Watergate year of 1974. In 1992, the Democrats won the White House for the first time since 1976.

But Republicans hope that international security will be on voters' minds come November. Bush's forceful response to the September 11 terrorist attacks has defined his presidency, in much the same way that the Cuban missile crisis raised the stature of the young Democratic president, John F. Ken-

\section{Vox Populi}

While the national population is approaching 300 million, less than three-fourths of the overall population in 2000 was of voting age (18 years old and above), slightly more than one-half were registered to vote, barely one-third participated in the last presidential election, and less than one-fourth cast ballots in the midterm House elections in 1998.

\section{U.S. Population (2000)}

Voting Age Population (2000)

Registered Voters (2000)

Votes cast for President (2000)

Votes cast for U.S. House (2000)

Votes cast for U.S. House (1998)

Sources: America Votes 23, 24; Washington Post, Dec. 29, 2000.
$281,421,906$

$205,814,000$

$159,049,775$

$105,396,627$

$97,226,268$

$65,896,772$ nedy, in the fall of 1962.

The events of that October 40 years ago also dramatically affected the year's elections, "freezing" the campaign at a critical stage that blunted the Republicans' chances for significant midterm gains. That November, the Democrats made the best midterm showing of any presidential party between 1934 and 1998, losing only four seats in the House, while gaining three in the Senate. If the

Republicans could post similar numbers in November, they would hold the House and regain the Senate.

Ultimately, though, who wins depends on who votes, and the turnout for a midterm election is often little more than two-thirds as large as a presidential election. The rule of thumb is that participation in midterm elections is disproportionately skewed to older, more affluent, and better-edu- 
cated voters. Yet the electorate also shows a growing number of independents - swing voters, if you will, who are not closely identified with either party.

It does not take a big swing to have a dramatic effect on the composition of Congress. When the GOP made its historic breakthrough in 1994, there was a swing of just 6 percentage points in the congressional vote from two year earlier, when the Democrats firmly controlled Congress. The Democratic share of the nationwide House vote declined from 51 percent in 1992 to 45 percent in 1994, while the Republican share rose a similar amount.

It was not a large swing, but enough to end one political era on Capitol Hill and launch another.

It would require a much smaller swing than that this year to break the tie in favor of one party or the other. Anything like the 6 percentage point swing of 1994 would likely usher in a new political era where ties are not allowed.

\section{House Reapportionment: The Top Three States Each Decade \\ Geographic power within the House of Representatives has shifted several times during the nation's history. Initially, it was \\ concentrated in states along the Atlantic Seaboard, led at first by Virginia; then, from the early 19th to the mid-20th century, \\ hegemony shifted to states of the industrial Frost Belt, led by New York and Pennsylvania; and since World War II, the fast-growing \\ states of the Sun Belt have been ascendant, led by California. \\ Listed below are the top three states in number of House seats for each decade. In 1920, there was a Census but no reapportionment.}

\begin{tabular}{|c|c|c|c|c|}
\hline \multirow[b]{2}{*}{ Census } & \multirow[b]{2}{*}{ Total House Seats } & \multicolumn{3}{|c|}{ Top Three States (and their number of seats) } \\
\hline & & First & Second & Third \\
\hline 1789 & 65 & Virginia (10) & Massachusetts, Pennsylvania (8) & \\
\hline 1790 & 106 & Virginia (19) & Massachusetts (14) & Pennsylvania (13) \\
\hline 1800 & 142 & Virginia (22) & Pennsylvania (18) & Massachusetts, New York (17) \\
\hline 1810 & 186 & New York (27) & Pennsylvania, Virginia (23) & \\
\hline 1820 & 213 & New York (34) & Pennsylvania (26) & Virginia (22) \\
\hline 1830 & 242 & New York (40) & Pennsylvania (28) & Virginia (21) \\
\hline 1840 & 232 & New York (34) & Pennsylvania (24) & Ohio (21) \\
\hline 1850 & 237 & New York (33) & Pennsylvania (25) & Ohio $(21)$ \\
\hline 1860 & 243 & New York (31) & Pennsylvania (24) & Ohio (19) \\
\hline 1870 & 293 & New York (33) & Pennsylvania (27) & Ohio (20) \\
\hline 1880 & 332 & New York (34) & Pennsylvania (28) & Ohio (21) \\
\hline 1890 & 357 & New York (34) & Pennsylvania (30) & Illinois (22) \\
\hline 1900 & 391 & New York (37) & Pennsylvania (32) & Illinois (25) \\
\hline 1910 & 435 & New York (43) & Pennsylvania (36) & Illinois (27) \\
\hline 1930 & 435 & New York (45) & Pennsylvania (34) & Illinois (27) \\
\hline 1940 & 435 & New York (45) & Pennsylvania (33) & Illinois (26) \\
\hline 1950 & 435 & New York (43) & California, Pennsylvania (30) & \\
\hline 1960 & 435 & New York (41) & California (38) & Pennsylvania (27) \\
\hline 1970 & 435 & California (43) & New York (39) & Pennsylvania (25) \\
\hline 1980 & 435 & California (45) & New York (34) & Texas (27) \\
\hline 1990 & 435 & California (52) & New York (31) & Texas (30) \\
\hline 2000 & 435 & California (53) & Texas (32) & New York (29) \\
\hline
\end{tabular}




\section{The Changing Composition of the 107th Congress}

The death of Democratic Sen. Paul Wellstone in a light plane crash Oct. 25 has roiled the political waters in the final days of the 2002 campaign. Wellstone was involved in a hotly contested reelection campaign in his home state of Minnesota that was considered one of the most pivotal races in the country. Minnesota Democrats nominated Walter F. Mondale as their replacement candidate for the Nov. 5 election. But it is up to outgoing Gov. Jesse Ventura, a member of the Independence Party of Minnesota, as to who - if anyone - fills the seat for the remaining days of the 107th Congress.

On the House side, there are three vacancies as election day approaches. A special election has been scheduled for Nov. 30 in Hawaii's 2nd District to fill the remaining weeks of the term of Democratic Rep. Patsy T. Mink, who died in late September. No special elections have been scheduled in Ohio to fill the two vacancies there.

Bold type indicates the number of seats held by the party controlling each chamber. Events that produced a vacancy are indicated in italics. "Ind." is an abbreviation for independents. "Vac." is an abbreviation for vacancies.

Date and Event

Nov. 7, 2000 - ELECTION

Dec. 8, 2000 - Rep. Julian C. Dixon (D-Calif. 32) dies

Feb. 3, 2001 - Rep. Bud Shuster (R-Pa. 9) resigns

March 29, 2001 - Rep. Norman Sisisky (D-Va. 4) dies

May 15, 2001 - Special election in Pa. 9th won by Bill Shuster (R)

May 28, 2001 - Rep. Joe Moakley (D-Mass. 9) dies

June 5, 2001 - Sen. James M. Jeffords (Vt.) switches from Republican to independent

June 5, 2001 - Special election in Calif. 32nd won by Diane E. Watson (D)

June 19, 2001 - Special election in Va. 4th won by J. Randy Forbes (R)

Aug. 6, 2001 -Rep. Asa Hutchinson (R-Ark. 3) resigns

Aug. 16, 2001 - Rep. Floyd Spence (R-S.C. 2) dies

Sept. 6, 2001 - Rep. Joe Scarborough (R-Fla. 1) resigns

Oct. 16, 2001 - Special elections in Fla. 1st and Mass 9th; Fla. 1st won by Jeff Miller (R), Mass. 9th by Stephen Lynch (D)

Nov. 20, 2001 - Special election in Ark. 3rd won by John Boozman (R)

Dec. 18, 2001 - Special election in S.C. 2nd won by Joe Wilson (R)

Jan. 8, 2002 - Special election in Okla. 1st won by John Sullivan (R) for seat of Rep. Steve Largent (R), vacated by resignation on Feb. 15, 2002

July 24, 2002 - Rep. James A Traficant Jr. (D-Ohio 17) expelled

August 1, 2002 - Rep. Virgil H. Goode (Va. 5) switches from independent to Republican

Sept. 9, 2002 - Rep. Tony P. Hall (D-Ohio 3) resigns

Sept. 28, 2002 - Rep. Patsy T. Mink (D-Hawaii 2) dies

Oct. 25, 2002 - Sen. Paul Wellstone (D-Minn.) dies in plane crash
House of Representatives

Senate

$\begin{array}{llllllll}\mathbf{R} & \mathbf{D} & \text { Ind. } & \text { Vac. } & \mathbf{R} & \mathbf{D} & \text { Ind. } & \text { Vac. }\end{array}$

$\begin{array}{lllllll}221 & 212 & 2 & 0 & \mathbf{5 0} & 50 & 0\end{array}$

$\begin{array}{llll}221 & 211 & 2 & 1\end{array}$

$\begin{array}{llll}220 & 211 & 2 & 2\end{array}$

$\begin{array}{llll}220 & 210 & 2 & 3\end{array}$

$\begin{array}{llll}221 & 210 & 2 & 2\end{array}$

$221209 \quad 2 \quad 3$

49

50

1

$\begin{array}{llll}\mathbf{2 2 1} & 210 & 2 & 2 \\ \mathbf{2 2 2} & 210 & 2 & 1 \\ \mathbf{2 2 1} & 210 & 2 & 2 \\ \mathbf{2 2 0} & 210 & 2 & 3 \\ \mathbf{2 1 9} & 210 & 2 & 4 \\ \mathbf{2 2 0} & 211 & 2 & 2\end{array}$

$\begin{array}{llll}\mathbf{2 2 1} & 211 & 2 & 1 \\ \mathbf{2 2 2} & 211 & 2 & 0 \\ \mathbf{2 2 2} & 211 & 2 & 0\end{array}$

$\begin{array}{llll}222 & 210 & 2 & 1\end{array}$

$\begin{array}{llll}223 & 210 & 1 & 1\end{array}$

$223 \quad 209 \quad 1 \quad 2$

$223 \quad 208 \quad 1 \quad 3$

$223 \quad 208 \quad 1 \quad 3$ 


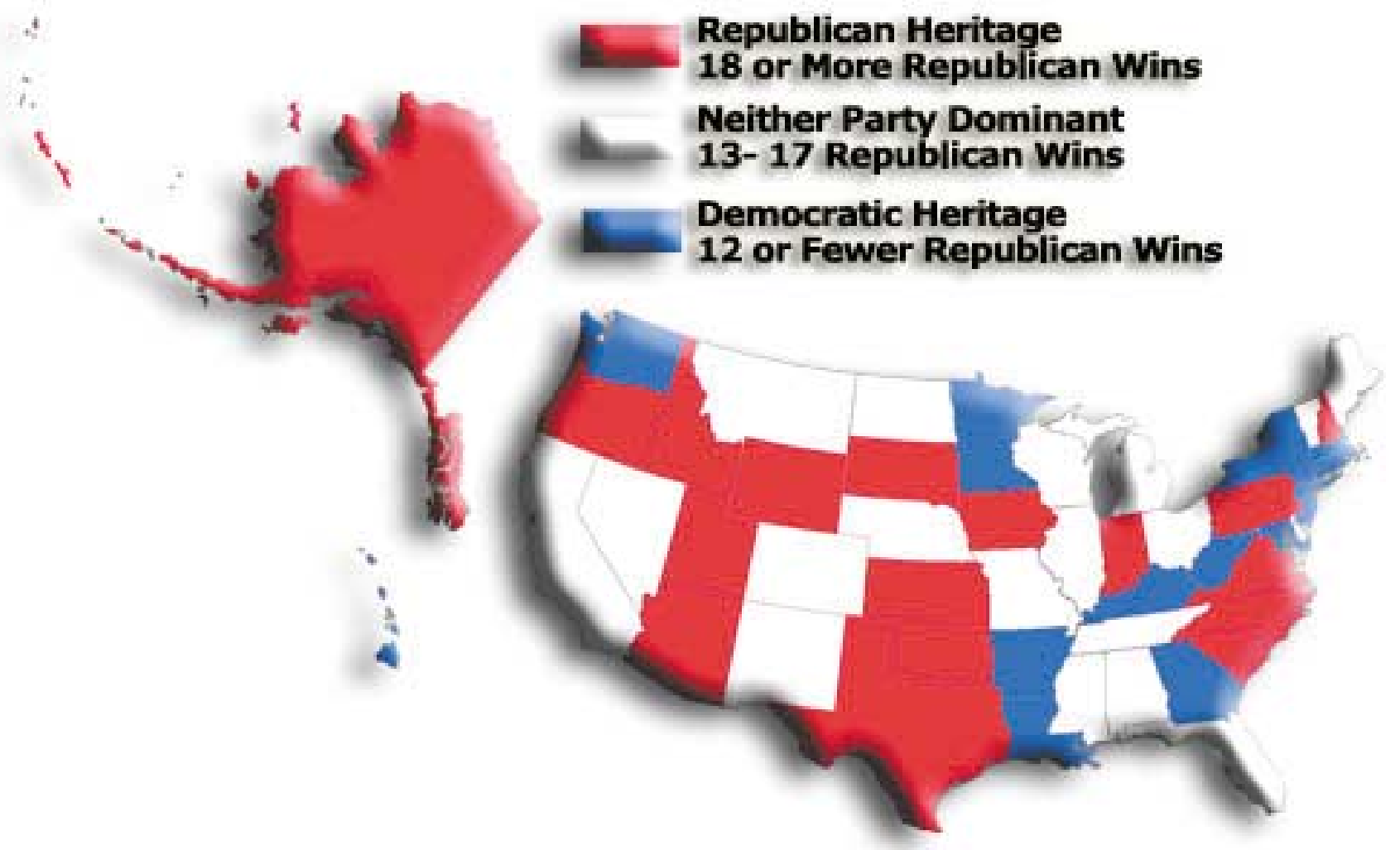

'Big Ticket' Races: Republican Victories in the Last 10 Elections

The following chart indicates the number of Republican victories for president, Senate and governor over the last 10 elections for each office, and a total for the aggregate number of victories for the three offices combined. The higher the number, the more Republican the terrain.

For president, the period covered is from 1964 through 2000. For Senate and governor, the period depends on the state. The starting point for Senate elections in most states is the early 1970s, and for gubernatorial elections, the early 1960s.

In bold type are the categories in which Republicans have won at least six of the last 10 elections. The Senate total in New Hampshire does not include the 1974 election which was so close that it was replayed in 1975.

\begin{tabular}{lcccc} 
& & NORTHEAST & & \\
State & President & Senate & Governor & Total Rep. Wins \\
\hline Connecticut & 5 & 2 & 3 & 10 \\
Delaware & 5 & 4 & 5 & 14 \\
Maine & 5 & $\mathbf{6}$ & 3 & 14 \\
Maryland & 3 & 2 & $\mathbf{6}$ & $\mathbf{6}$ \\
Massachusetts & 2 & 1 & $\mathbf{7}$ & 22 \\
New Hampshire & $\mathbf{7}$ & $\mathbf{8}$ & 5 & 12 \\
New Jersey & $\mathbf{6}$ & 1 & 5 & 12 \\
New York & 3 & 4 & $\mathbf{6}$ & 19 \\
Pennsylvania & 4 & $\mathbf{9}$ & 5 & 12 \\
Rhode Island & 2 & 5 & 2 & 13 \\
Vermont & $\mathbf{6}$ & 5 & 4 & 7 \\
West Virginia & 3 & 0 & & \\
\hline
\end{tabular}




\begin{tabular}{|c|c|c|c|c|}
\hline & & MIDWES & & \\
\hline State & President & Senate & Governor & Total Rep. Wins \\
\hline Illinois & 6 & 3 & 8 & 17 \\
\hline Indiana & 9 & 9 & 5 & 23 \\
\hline lowa & 5 & 5 & 9 & 19 \\
\hline Kansas & 9 & 10 & 4 & 23 \\
\hline Michigan & 5 & 2 & 8 & 15 \\
\hline Minnesota & 1 & 6 & 4 & 11 \\
\hline Missouri & 6 & 7 & 4 & 17 \\
\hline Nebraska & 9 & 2 & 4 & 15 \\
\hline North Dakota & 9 & 1 & 4 & 14 \\
\hline Ohio & 6 & 3 & 7 & 16 \\
\hline South Dakota & 9 & 4 & 7 & 20 \\
\hline Wisconsin & 4 & 2 & 7 & 13 \\
\hline & & SOUTH & & \\
\hline State & President & Senate & Governor & Total Rep. Wins \\
\hline Alabama & 8 & 3 & 3 & 14 \\
\hline Arkansas & 5 & 1 & 2 & 8 \\
\hline Florida & 7 & 3 & 3 & 13 \\
\hline Georgia & 6 & 3 & 0 & 9 \\
\hline Kentucky & 6 & 4 & 1 & 11 \\
\hline Louisiana & 6 & 0 & 3 & 9 \\
\hline Mississippi & 8 & 7 & 2 & 17 \\
\hline North Carolina & 8 & 7 & 3 & 18 \\
\hline Oklahoma & 9 & 7 & 5 & 21 \\
\hline South Carolina & 9 & 5 & 4 & 18 \\
\hline Tennessee & 6 & 5 & 5 & 16 \\
\hline Texas & 7 & 7 & 4 & 18 \\
\hline Virginia & 9 & 7 & 5 & 21 \\
\hline & & WEST & & \\
\hline State & President & Senate & Governor & Total Rep. Wins \\
\hline Alaska & 9 & 9 & 3 & 21 \\
\hline Arizona & 9 & 7 & 7 & 23 \\
\hline California & 6 & 3 & 6 & 15 \\
\hline Colorado & 8 & 5 & 4 & 17 \\
\hline Hawaii & 2 & 0 & 0 & 2 \\
\hline Idaho & 9 & 9 & 4 & 22 \\
\hline Montana & 8 & 3 & 5 & 16 \\
\hline Nevada & 7 & 4 & 3 & 14 \\
\hline New Mexico & 6 & 6 & 5 & 17 \\
\hline Oregon & 5 & 8 & 5 & 18 \\
\hline Utah & 9 & 10 & 5 & 24 \\
\hline Washington & 4 & 4 & 4 & 12 \\
\hline Wyoming & 9 & 10 & 5 & 24 \\
\hline
\end{tabular}




\section{Longest Current Winning Streaks in Gubernatorial and Senate Races}

The following chart indicates states in which one party has won five or more consecutive elections for senator or governor. An asterisk (*) indicates that Republican Howard "Bo" Callaway won the popular vote for governor of Georgia in 1966 but fell short of the required majority. Democrat Lester Maddox was subsequently elected governor by the state legislature. The last governor of Georgia who was not a Democrat was a Liberal Republican (LR), elected during the post-Civil War Reconstruction period. A pound sign (\#) indicates that no Republican has been elected to the Senate from Louisiana since direct popular vote for the office was instituted nationally in 1913.

\section{SENATE}

State

Region

Party

Consecutive Wins

Last Win by Opposing Party

Louisiana

Kansas

West Virginia

Hawaii

Utah

Wyoming

Massachusetts

New Jersey

Alaska

Idaho

New Hampshire

North Dakota

Maryland

Connecticut

Mississippi

California

Texas

Wisconsin

GOVERNOR

State

Georgia

Hawaii

Kentucky

Maryland

Illinois

South Dakota

Utah

Vermont

Washington

$\begin{array}{cll}\text { South } & \text { Dem. } & 32 \text { \# } \\ \text { Midwest } & \text { Rep. } & 24 \\ \text { East } & \text { Dem. } & 16 \\ \text { West } & \text { Dem. } & 11 \\ \text { West } & \text { Rep. } & 10 \\ \text { West } & \text { Rep. } & 10 \\ \text { East } & \text { Dem. } & 9 \\ \text { East } & \text { Dem. } & 9 \\ \text { West } & \text { Rep. } & 8 \\ \text { West } & \text { Rep. } & 8 \\ \text { East } & \text { Rep. } & 8 \\ \text { Midwest } & \text { Dem. } & 8 \\ \text { East } & \text { Dem. } & 7 \\ \text { East } & \text { Dem. } & 6 \\ \text { South } & \text { Rep. } & 6 \\ \text { West } & \text { Dem. } & 5 \\ \text { South } & \text { Rep. } & 5 \\ \text { Midwest } & \text { Dem. } & 5\end{array}$

5
(No Rep. win since popular vote for Senate initiated in 1913)

George McGill (D), 1932

Chapman Revercomb (R), 1956

Hiram L. Fong (R), 1970

Frank E. Moss (D), 1970

Gale McGee (D), 1970

Edward W. Brooke (R), 1972

Clifford P. Case (R), 1972

Mike Gravel (D), 1974

Frank Church (D), 1974

John A. Durkin (D), 1975

Mark Andrews (R), 1980

Charles Mathias (R), 1980

Lowell P. Weicker (R), 1982

John Stennis (D), 1982

Pete Wilson (R), 1988

Lloyd Bentsen (D), 1988

Robert W. Kasten (R), 1986

Region Party Consecutive Wins Last Win by Opposing Party

South Dem. $\quad 50^{*} \quad$ James M. Smith (LR), 1872

West

Dem.

William F. Quinn (R), 1959

Louie B. Nunn (R), 1967

Spiro T. Agnew (R), 1966

Daniel Walker (D), 1972

Richard F. Kneip (D), 1974

Scott M. Matheson (D), 1980

Richard A. Snelling (R), 1990

John D. Spellman (R), 1980 


\title{
The 2002 Congressional Elections
}

\section{Do the Math, and the Result Is: Not Much of a Contest}

\author{
By Rhodes Cook
}

As originally published in The Washington Post Outlook section on October 6, 2002.

$\mathrm{R}$ epublican Mike Rogers of Michigan seems like the perfect target for the Democrats as they did the incumbent freshman win his 2000 race by the smallest margin in the country - 111 votes but he represents a district that switched back and forth between the parties three times during the Clinton years.

Yet Rogers's seat is widely regarded as safe for the Republicans. How come? Certainly his fundraising has gone well - his campaign had amassed more than $\$ 700,000$ by the middle of last year. But just as important has been the redistricting effort of the GOP-controlled state legislature, which made Rogers's Lansing-area district significantly more Republican and significantly less competitive than it was two years ago.

Rogers has plenty of company. Scores of incumbents will face little or no competition in their quest to return to Washington next year, and many of them can thank the redistricters. So when the media machine revs up for its usual breathless coverage about "the battle for the House" and you see those big color-coded maps on Election Night, remember that the vast majority of those 435 House seats were decided months before any voter pulled a lever or pressed a touch screen.

The power of incumbency is a well-established fact of political life. But incumbent protection became the dominant theme of this round of congressional redistricting - assisted by ever more sophisticated computer programs that can track demographic changes block by block. The result is that you won't need a scorecard to tell the players - because there aren't that many to keep tabs on. Most political handicappers say that no more than 40 to 50 of this year's House races will be "competitive" (won by a candidate who receives less than 55 percent of the vote).

The competition was much fiercer in 1992, after the last round of redistricting. Then, the House banking scandal (remember that?), the widespread worry about a

\section{Competitive House Races Since 1990}

The amount of competition for House seats often dwindles as a decade winds down, but picks up again with a new round of redistricting. Such was the case in 1992, and the level of competition and partisan change remained high through 1996. The partisan shift in House seats is measured from immediately before to immediately after each election.

\begin{tabular}{c|c|c|c}
\hline \multirow{2}{*}{ Election } & Competitive Races & \multicolumn{2}{|c}{ Seats Changing Party Hands } \\
\cline { 2 - 4 } & (Sub-55\% Winners) & Total Changes & Net Change \\
\hline 1990 & 57 & 21 & Dems gain 9 \\
1992 & 111 & 43 & Reps gain 10 \\
1994 & 98 & 60 & Reps gain 52 \\
1996 & 94 & 35 & Dems gain 9 \\
1998 & 47 & 17 & Dems gain 5 \\
2000 & 57 & 18 & Dems gain 2
\end{tabular}

Source: For changes in House seats, Vital Statistics on Congress 19992000 (The AEl Press). 
recession and an anti-incumbent sentiment personified by Ross Perot's maverick presidential candidacy all served to roil the political waters. More than one out of every four House contests (111) that year was won with less than 55 percent of the vote, and two dozen incumbents lost. The 1994 election continued this trend, producing the Republican Revolution that ended 40 years of Democratic control of the House and the Senate. But in the 2000 election, barely one of every eight House races (57) was won with less than 55 percent, and only six incumbents were defeated (others resigned or ran for different offices, creating more turnover but not necessarily more competition).

This fall, recession is back, the threat of war is in the air and redistricting has rearranged the boundaries of practically every district in the country. It would seem the perfect environment for turmoil in congressional races from coast to coast. But with the House of Representatives about as closely divided as it has been at any point in nearly a half century (223 Republicans, 208 Democrats, 3 Democratic vacancies and 1 independent), the two parties have opted to be safe rather than sorry.

California has led the way. The Golden State's ruling Democrats, who employed partisan redistricting with a vengeance in the 1980s, decided this time to consolidate their recent election gains with a map that is expected to maintain the status quo of 32 Democrats and 20 Republicans. In the nation's largest delegation, only one seat appears up for grabs. "It was like a kids' birthday party," University of Oklahoma political scientist Keith Gaddie said of the California redistricting. "Everybody got a prize."

And there have been prizes galore, all around the country. The corporal's guard of vulnerable incumbents numbers around two dozen. About half the competitive seats this year are open, either newly created by reapportionment or in the process of being vacated by a departing incumbent.

To be sure, partisan redistricting has created some interesting battlegrounds in several states where one party controlled all the levers of redistricting (the governorship and both chambers of the state legislature). Republicans, for example, are hoping to gain a few seats from their line drawing in Michigan and Pennsylvania, which Democrats hope to offset with their creative cartography in states such as Georgia and Maryland.

But in big states such as California, Texas and Illinois, it is hard to find more than a single competitive race - or any at all in New York, Ohio and Michigan. Those half dozen states contain almost 40 percent of the nation's congressional districts, but they are almost entirely removed from this fall's action.

The current muting of competition, as anti-democratic as it may seem, has a certain logic.

Incumbent protection served as the path of least resistance for state legislatures redrawing the lines. Unlike in 1992, there were comparatively few retirements this time that would naturally create competitive open-seat districts. And there are fewer districts that are competitive by nature of their internal contradictions - for example, voting for one party's candidate for president and the other party's for Congress. In 2000, the number of such "split-ticket" districts was at its lowest level in nearly 50 years.

Neither party wants to lose its hard-won gains. With the partisan balance almost even, every seat counts.

It is a far different situation than a decade ago, when the Democrats approached the 1992 elections with a huge 100-seat advantage in the House. Republicans had barely a toehold in the redistrict- 
ing process in many states, but they had a powerful ally in President George H. W. Bush's Justice Department. It used the Voting Rights Act to encourage the creation of more majority-minority districts across the South, at the same time diminishing the minority vote in adjoining districts that had sustained white Democrats.

The effects were not felt immediately. But when the political winds shifted dramatically in the Republicans' favor in 1994, the GOP was poised for its historic breakthrough. More than one out of every four House seats has shifted party hands at least once since 1992, and the South has been transformed from the cornerstone of the Democratic House majority to the building block of GOP control.

The lines this time have not been drawn with the expectation of dramatic upheaval. But there is the potential for small shifts - either now or later in the decade - that could tip the balance in a closely divided House.

Prime targets are the roughly 30 districts that elected one party's House candidate in 2000 while voting decisively for the other party's presidential candidate. The group is nearly evenly divided between a band of moderate Frost Belt Republicans and a cadre of centrist Southern and border state Democrats including six from Texas alone.

One of the Republicans who must run this year in hostile terrain is Maryland's Constance A. Morella, whose revamped Montgomery County district cast roughly two-thirds of its ballots for Democrat $\mathrm{Al}$ Gore in the last presidential election. Reelected to an eighth term in 2000 with just 52 percent of the vote, Morella is considered one of the House's most endangered incumbents.

As this decade unfolds, more of these "misfit" seats may become competitive, as incumbents either become vulnerable or they opt to retire. Such a development would create more opportunity for change on Capitol Hill. And that would be all to the good for those who would like to see a true battle for the House rather than a rerun of past elections.

\section{Paired Incumbents: They Could Prove Decisive}

Once every decade, several pairs of House members are thrown together in the same constituency by congressional redistricting. Rarely, does the outcome of these handful of races make a difference in determining control of the House. But this year they could.

Three of the four contests involving paired incumbents this fall are being waged in districts that voted heavily for George W. Bush in 2000 (based on the last vote for president compiled for this year's districts by the Republican National Committee). Another favorable sign for Republicans is the trend established in the primaries. In the four intraparty contests between incumbents, the more senior member won each time. Of the four sets of paired incumbents this fall, the Republican is the senior member in each race.

\begin{tabular}{|c|c|c|c|c|c|c|c|}
\hline & DEMOCRATS & & & REPUBLICANS & & & \\
\hline District & Incumbent & Terms & ${ }^{\circ 00} \underset{\%}{ }$ & Incumbent & Terms & $\begin{array}{c}00 \text { Win } \\
\%\end{array}$ & Terrain \\
\hline Conn. 5 & James Maloney & 3 & $53.6 \%$ & Nancy Johnson & 10 & $62.6 \%$ & $\begin{array}{l}\text { Pro-Dem. } \\
\text { (Bush 43\%) }\end{array}$ \\
\hline III. 19 & David Phelps & 2 & $64.6 \%$ & John Shimkus & 3 & $63.1 \%$ & $\begin{array}{l}\text { Pro-Rep. } \\
\text { (Bush 58\%) }\end{array}$ \\
\hline Miss. 3 & Ronnie Shows & 2 & $58.1 \%$ & $\begin{array}{l}\text { Charles "Chip" } \\
\text { Pickering }\end{array}$ & 3 & $73.2 \%$ & $\begin{array}{l}\text { Pro-Rep. } \\
\text { (Bush 65\%) }\end{array}$ \\
\hline Pa. 17 & Tim Holden & 5 & $66.3 \%$ & George Gekas & 10 & $71.5 \%$ & $\begin{array}{l}\text { Pro-Rep. } \\
\text { (Bush 57\%) }\end{array}$ \\
\hline
\end{tabular}




\section{The Marginal 57:}

\section{House Members Elected in 2000 with Less Than 55\% of the Vote}

A total of 57 House members were elected in 2000 with less than $55 \%$ of the total vote - a group nearly evenly divided between Democrats (28) and Republicans (29). The level of competitiveness in their races, however, varied considerably. Just 42 members were elected two years ago by a margin of less than 10 percentage points. Barely two dozen members were elected with less than $52 \%$ of the vote.

If history is a guide, the incumbents on this list most likely to have trouble in 2002 are freshmen in highly competitive districts and declining or low-flying incumbents, who have been winning in recent years by dwindling margins.

Many of the incumbents on this list had their districts made safer in the recent round of redistricting. Those with "Friendly" terrain are in Republican-held districts where George W. Bush received at least 55\% of the presidential vote in 2000 or Democratic-held districts where Bush drew less than 45\%. Those with "Marginal" terrain are in districts where Bush drew between $45 \%$ and $55 \%$ of the vote. Those with "Hostile" terrain are in Democratic-held districts where Bush polled at least 55\% of the vote or Republican-held districts where Bush was held to less than $45 \%$. The Bush percentages were compiled by the Republican National Committee to reflect the new congressional district lines.

For some members, the recent vote on the use of force against Iraq could be a key issue. The resolution passed the House Oct. 10 by a vote of 296-to-133, with 126 Democrats, six Republicans and one independent voting "No." A dash (-) in the chart below indicates that Rep. James A. Traficant had been expelled from the House before the vote was taken. Traficant is running for a seat in the 108th Congress as an independent in a district where the terrain is favorable to a Democrat.

Several members on this list have announced their retirement or are running for other office. They are listed in italics. Members are listed according to the district in which they were elected in 2000.

Democratic Marginals

2000 Election Results

\begin{tabular}{|c|c|c|c|c|c|}
\hline \multirow[b]{2}{*}{ Member } & \multirow[b]{2}{*}{$\begin{array}{l}\text { Current } \\
\text { Term }\end{array}$} & & \multirow[b]{2}{*}{ Iraq Vote } & \multirow[b]{2}{*}{ Terrain } \\
\hline & & $\begin{array}{c}\% \text { of } \\
\text { Total Vote }\end{array}$ & $\begin{array}{l}\text { Victory Margin } \\
\text { (in Total Vote) }\end{array}$ & & \\
\hline Steve J. Israel, D-N.Y. 2 & 1 & $47.9 \%$ & $13.0 \%$ & $\mathrm{Y}$ & Friendly \\
\hline Betty McCollum, D-Minn. 4 & 1 & $48.0 \%$ & $17.1 \%$ & $\mathbf{N}$ & Friendly \\
\hline Jane Harman, D-Calif. 36 & 4 & $48.4 \%$ & $1.9 \%$ & $\mathrm{Y}$ & Friendly \\
\hline Rush Holt, D-N.J. 12 & 2 & $48.7 \%$ & $0.2 \%$ & $\mathbf{N}$ & Friendly \\
\hline Susan A. Davis, D-Calif. 49 & 1 & $49.6 \%$ & $3.4 \%$ & $\mathbf{N}$ & Friendly \\
\hline William P. Luther, D-Minn. 6 & 4 & $49.6 \%$ & $1.6 \%$ & $\mathrm{Y}$ & Marginal \\
\hline Dennis Moore, D-Kan. 3 & 2 & $50.0 \%$ & $3.1 \%$ & Y & Marginal \\
\hline James A. Traficant, D-Ohio 17 & 9 & $50.0 \%$ & $27.3 \%$ & - & Friendly (to Dem.) \\
\hline Rick Larsen, D-Wash. 2 & 1 & $50.0 \%$ & $4.1 \%$ & $\mathbf{N}$ & Marginal \\
\hline Mike Ross, D-Ark. 4 & 1 & $51.0 \%$ & $2.0 \%$ & $\mathrm{Y}$ & Marginal \\
\hline Tammy Baldwin, D-Wis. 2 & 2 & $51.4 \%$ & $2.8 \%$ & $\mathbf{N}$ & Friendly \\
\hline Timothy J. Roemer, D-Ind. 3 & 6 & $51.6 \%$ & $4.2 \%$ & $Y$ & Marginal \\
\hline Shelley Berkley, D-Nev. 1 & 2 & $51.7 \%$ & $7.5 \%$ & $\mathrm{Y}$ & Friendly \\
\hline Cal Dooley, D-Calif. 20 & 6 & $52.3 \%$ & $6.8 \%$ & $Y$ & Friendly \\
\hline Ellen O. Tauscher, D-Calif. 10 & 3 & $52.6 \%$ & $8.4 \%$ & $\mathrm{Y}$ & Friendly \\
\hline Adam Schiff, D-Calif. 27 & 1 & $52.7 \%$ & $8.9 \%$ & $\mathrm{Y}$ & Friendly \\
\hline Joseph M. Hoeffel, D-Pa. 13 & 2 & $52.8 \%$ & $7.1 \%$ & $\mathrm{Y}$ & Friendly \\
\hline Earl Pomeroy, D-N.D. AL & 5 & $52.9 \%$ & $8.4 \%$ & $\mathrm{Y}$ & Hostile \\
\hline Lois Capps, D-Calif. 22 & 2 & $53.1 \%$ & $8.8 \%$ & $\mathbf{N}$ & Friendly \\
\hline Sanford Bishop, D-Ga. 2 & 5 & $53.5 \%$ & $7.0 \%$ & Y & Marginal \\
\hline James H. Maloney, D-Conn. 5 & 3 & $53.6 \%$ & $9.3 \%$ & $\mathbf{N}$ & Friendly \\
\hline Baron Hill, D-Ind. 9 & 2 & $54.2 \%$ & $10.4 \%$ & $Y$ & Hostile \\
\hline Mike Honda, D-Calif. 15 & 1 & $54.3 \%$ & $12.1 \%$ & $\mathbf{N}$ & Friendly \\
\hline
\end{tabular}




\begin{tabular}{|c|c|c|c|c|c|}
\hline \multirow[b]{2}{*}{ Member } & \multirow[b]{2}{*}{$\begin{array}{l}\text { Current } \\
\text { Term }\end{array}$} & \multicolumn{2}{|c|}{2000 Election Results } & \multirow[b]{2}{*}{ Iraq Vote } & \multirow[b]{2}{*}{ Terrain } \\
\hline & & $\begin{array}{c}\% \text { of } \\
\text { Total Vote }\end{array}$ & $\begin{array}{l}\text { Victory Margin } \\
\text { (in Total Vote) }\end{array}$ & & \\
\hline Ken Lucas, D-Ky. 4 & 2 & $54.3 \%$ & $10.8 \%$ & $\mathrm{Y}$ & Hostile \\
\hline Jay Inslee, D-Wash. 1 & 3 & $54.6 \%$ & $12.0 \%$ & $\mathbf{N}$ & Friendly \\
\hline Chet Edwards, D-Texas 11 & 6 & $54.8 \%$ & $10.5 \%$ & Y & Hostile \\
\hline Lane Evans, D-III. 17 & 10 & $54.9 \%$ & $9.8 \%$ & $\mathbf{N}$ & Friendly \\
\hline Brad Carson, D-Okla. 2 & 1 & $54.9 \%$ & $13.1 \%$ & $\mathrm{Y}$ & Marginal \\
\hline \multicolumn{6}{|l|}{ Republican Marginals } \\
\hline & & \multicolumn{2}{|c|}{2000 Election Results } & & \\
\hline Member & $\begin{array}{c}\text { Current } \\
\text { Term }\end{array}$ & $\begin{array}{c}\% \text { of } \\
\text { Total Vote }\end{array}$ & $\begin{array}{l}\text { Victory Margin } \\
\text { (in Total Vote) }\end{array}$ & Iraq Vote & Terrain \\
\hline Mark Kennedy, R-Minn. 2 & 1 & $48.1 \%$ & $0.1 \%$ & Y & Marginal \\
\hline Steve Horn, R-Calif. 38 & 5 & $48.4 \%$ & $0.9 \%$ & $Y$ & Hostile \\
\hline Shelley Moore Capito, R-W.V. 2 & 1 & $48.5 \%$ & $2.6 \%$ & Y & Marginal \\
\hline Mike Rogers, R-Mich. 8 & 1 & $48.8 \%$ & $0.1 \%$ & Y & Marginal \\
\hline Clay Shaw, R-Fla. 22 & 11 & $50.1 \%$ & $0.2 \%$ & Y & Marginal \\
\hline Heather A. Wilson, R-N.M. 1 & 2 & $50.3 \%$ & $7.0 \%$ & Y & Marginal \\
\hline Rob Simmons, R-Conn. 2 & 1 & $50.6 \%$ & $1.2 \%$ & Y & Hostile \\
\hline Ric Keller, R-Fla. 8 & 1 & $50.8 \%$ & $1.6 \%$ & Y & Marginal \\
\hline Mike Pence, R-Ind. 2 & 1 & $50.9 \%$ & $12.1 \%$ & Y & Friendly \\
\hline Samuel B. Graves Jr., R-Mo. 6 & 1 & $50.9 \%$ & $4.1 \%$ & Y & Marginal \\
\hline Mark Steven Kirk, R-III. 10 & 1 & $51.2 \%$ & $2.4 \%$ & Y & Marginal \\
\hline Dennis Rehberg, R-Mont. AL & 1 & $51.5 \%$ & $5.2 \%$ & Y & Friendly \\
\hline Mike Ferguson, R-N.J. 7 & 1 & $51.6 \%$ & $6.0 \%$ & Y & Marginal \\
\hline Constance A. Morella, R-Md. 8 & 8 & $52.0 \%$ & $6.5 \%$ & $\mathbf{N}$ & Hostile \\
\hline Edward L. Schrock, R-Va. 2 & 1 & $52.0 \%$ & $4.0 \%$ & Y & Friendly \\
\hline Don Sherwood, R-Pa. 10 & 2 & $52.6 \%$ & $5.2 \%$ & Y & Friendly \\
\hline John Hostettler, R-Ind. 8 & 4 & $52.7 \%$ & $7.4 \%$ & $\mathbf{N}$ & Friendly \\
\hline Ernest Fletcher, R-Ky. 6 & 2 & $52.8 \%$ & $18.0 \%$ & $\mathrm{Y}$ & Friendly \\
\hline Anne M. Northup, R-Ky. 3 & 3 & $52.9 \%$ & $8.7 \%$ & $\mathrm{Y}$ & Marginal \\
\hline John E. Sununu, R-N.H. 1 & 3 & $52.9 \%$ & $7.8 \%$ & $Y$ & Marginal \\
\hline Pat Tiberi, R-Ohio 12 & 1 & $52.9 \%$ & $9.1 \%$ & $\mathrm{Y}$ & Marginal \\
\hline Steve Chabot, R-Ohio 1 & 4 & $53.0 \%$ & $8.4 \%$ & Y & Marginal \\
\hline Tim Johnson, R-III. 15 & 1 & $53.2 \%$ & $6.4 \%$ & Y & Friendly \\
\hline Pat Toomey, R-Pa. 15 & 2 & $53.2 \%$ & $6.5 \%$ & Y & Marginal \\
\hline Jeff Flake, R-Ariz. 1 & 1 & $53.6 \%$ & $11.2 \%$ & Y & Friendly \\
\hline Tom Tancredo, R-Colo. 6 & 2 & $53.9 \%$ & $11.8 \%$ & Y & Friendly \\
\hline Pete Sessions, R-Texas 5 & 3 & $54.0 \%$ & $9.6 \%$ & Y & Friendly \\
\hline Elton Gallegly, R-Calif. 23 & 8 & $54.1 \%$ & $13.4 \%$ & Y & Marginal \\
\hline Todd Tiahrt, R-Kan. 4 & 4 & $54.4 \%$ & $12.4 \%$ & $\mathrm{Y}$ & Friendly \\
\hline
\end{tabular}




\section{'Sea of Red,' the Iraq Vote, and the 2002 Senate Lineup}

Republicans have liked the look of the electoral battlefield for this fall's Senate races. Although they are defending six more seats than the Democrats (20 to 14), including three more open seats (5 to 2), all but a trio of seats that the GOP is defending are in "Red America" - states that favored George W. Bush in the last election.

Yet the correlation between presidential and Senate voting is not always that strong. Just look at the wall-to-wall Democratic senators in the Dakotas. Still, few Democrats running for reelection this year are putting much distance between themselves and President Bush. The Senate vote Oct. 11 to authorize the president to use military force to disarm Iraq passed by a vote of 77-to-23. Only four senators up for election this year voted "no," all Democrats running in states carried by Al Gore in 2000. And only one of the four - the late Paul Wellstone of Minnesota - was involved in a hotly contested race.

In italics are the names of retiring senators (as well as Wellstone and Democrat Robert Torricelli of New Jersey, who dropped his Senate bid in late September). An asterisk (*) indicates senators who were elected to a first term in 1996. A pound sign (\#) denotes the special case of Missouri's Jean Carnahan, who was appointed to her Senate seat.

\begin{tabular}{|c|c|c|c|c|c|}
\hline \multirow[b]{2}{*}{ State } & \multirow[b]{2}{*}{ 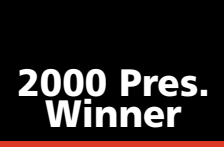 } & \multicolumn{4}{|c|}{2002 Senate Seats Up (with 1996 Margins of Victory) } \\
\hline & & Republicans & Iraq Vote & Democrats & Iraq Vote \\
\hline \multicolumn{6}{|l|}{ Bush States } \\
\hline Idaho & Bush by $\mathbf{4 0} \%$ & Craig by $17 \%$ & $\mathbf{Y}$ & & \\
\hline Wyoming & Bush by $40 \%$ & Enzi by $12 \%$ * & $\mathbf{Y}$ & & \\
\hline Alaska & Bush by $31 \%$ & Stevens by $64 \%$ & $\mathbf{Y}$ & & \\
\hline Nebraska & Bush by $29 \%$ & Hagel by $14 \%$ * & $\mathbf{Y}$ & & \\
\hline Montana & Bush by $25 \%$ & & & Baucus by $5 \%$ & $\mathbf{Y}$ \\
\hline South Dakota & Bush by $23 \%$ & & & Johnson by 3\%* & $\mathbf{Y}$ \\
\hline Oklahoma & Bush by $22 \%$ & Inhofe by $17 \%$ & $\mathbf{Y}$ & & \\
\hline Kansas & Bush by $21 \%$ & Roberts by $28 \%$ * & $\mathbf{Y}$ & & \\
\hline Texas & Bush by $21 \%$ & Gramm by $11 \%$ & $\mathbf{Y}$ & & \\
\hline Mississippi & Bush by $17 \%$ & Cochran by $44 \%$ & $\mathbf{Y}$ & & \\
\hline South Carolina & Bush by $16 \%$ & Thurmond by $9 \%$ & $\mathbf{Y}$ & & \\
\hline Alabama & Bush by $15 \%$ & Sessions by $7 \%$ * & Y & & \\
\hline Kentucky & Bush by $15 \%$ & McConnell by $13 \%$ & $\mathbf{Y}$ & & \\
\hline North Carolina & Bush by $13 \%$ & Helms by 7\% & $\mathbf{Y}$ & & \\
\hline Georgia & Bush by $12 \%$ & & & Cleland by $1 \%$ & $\mathbf{Y}$ \\
\hline Colorado & Bush by $8 \%$ & Allard by $5 \%$ * & Y & & \\
\hline Louisiana & Bush by $8 \%$ & & & Landrieu by $0.4 \% *$ & $\mathbf{Y}$ \\
\hline Virginia & Bush by $8 \%$ & J. Warner by $5 \%$ & $\mathbf{Y}$ & & \\
\hline West Virginia & Bush by $6 \%$ & & & Rockefeller by $53 \%$ & $\mathbf{Y}$ \\
\hline Arkansas & Bush by $5 \%$ & Hutchinson by $5 \%$ * & $\mathbf{Y}$ & & \\
\hline Tennessee & Bush by $4 \%$ & Thompson by $25 \%$ & $\mathbf{Y}$ & & \\
\hline Missouri & Bush by $3 \%$ & & & J. Carnahan \# & Y \\
\hline New Hampshire & Bush by $1 \%$ & Bob Smith by 3\% & $\mathbf{Y}$ & & \\
\hline
\end{tabular}


2002 Senate Seats Up (with 1996 Margins of Victory)

State 2000 Pres.

Republicans Iraq Vote Democrats Iraq Vote

Gore States

New Mexico

Gore by $0.1 \%$

lowa Gore by $0.3 \%$

Domenici by $35 \%$

$\mathbf{Y}$

Oregon

Gore by $0.5 \%$

Minnesota

Gore by $2 \%$

Maine

Gore by $\mathbf{5 \%}$

Michigan

Gore by $5 \%$

Illinois

Gore by $12 \%$

Delaware

Gore by $13 \%$

New Jersey

Gore by $16 \%$

Massachusetts

Gore by $\mathbf{2 7 \%}$

Rhode Island

Gore by $29 \%$

Gordon Smith by $4 \%$ *

Harkin by $5 \%$

$Y$

Wellstone by $9 \% \quad$ N

Collins by $5 \%$ *

Y

\begin{tabular}{|cc}
\hline Wellstone by $9 \%$ & N \\
\hline Levin by $19 \%$ & N \\
\hline Durbin by $15 \% *$ & N \\
\hline Biden by $22 \%$ & Y \\
\hline Torricelli by $10 \% *$ & Y \\
Kerry by $8 \%$ & Y \\
Reed by $28 \% *$ & N
\end{tabular}

\section{The Battle for the Senate: A Strange Finish}

The battle for the Senate had a fixed shape to it for much of the year, as retirements were limited to a quartet of Southern Republicans. But since Labor Day, three more Senate seats have come open in other parts of the country, only the first of which was even vaguely expected.

That was in New Hampshire, where embattled Republican incumbent Bob Smith lost his party's Senate primary to Rep. John E. Sununu. But barely a fortnight later, Democratic Sen. Robert Torricelli abandoned his bid for reelection in New Jersey under an ethics cloud. And in a shocking tragedy less than two weeks before the election, Democratic Sen. Paul Wellstone died in a plane crash in his home state of Minnesota.

Democrats in Minnesota and New Jersey have turned to a pair of septuagenarian former senators as replacement candidates - Frank Lautenberg in New Jersey and Walter F. Mondale in Minnesota.

While both are favored to win their truncated campaigns, neither by any means could be considered a lock. Lautenberg won three previous Senate elections - in 1982, 1988 and 1994 - but always by a margin of less than 10 percentage points.

Meanwhile, Mondale won two previous Senate elections - in 1966 and 1972 - before becoming Jimmy Carter's vice president. His last time on the Minnesota ballot was as the Democratic presidential nominee in 1984, when he carried his home state by a margin of just 3,761 votes out of more than 2 million cast.

Another race that close Nov. 5 would be rather fitting in a Senate where the partisan balance between the Democrats and Republicans stands even at 49 apiece. 


\section{Third Party/lndependent Governors Since 1990}

In the last dozen years, third party and independent candidates have had their greatest success in races for governor. And that should be the case again this year, with former Democratic Rep. Tim Penny standing a decent chance of winning the governorship of Minnesota on the Independence Party line.

Following is a list of those candidates who have been elected governor since 1990 running as an independent or third-party nominee. Three of the four had their political roots in one of the two major parties. Hickel and Weicker were former Republican officeholders; King, a former Democrat. Of the four, only King sought an additional term as governor, although Hickel had served a previous term as a Republican. The winning percentage represents each candidate's share of the total vote.

\begin{tabular}{llllll}
\hline Candidate & State & Party & Year & Win \% & Reelection Status \\
\hline Walter J. Hickel & Alaska & Alaskan Independence & 1990 & $38.9 \%$ & Did not seek reelection in 1994 \\
Lowell P. Weicker & Connecticut & A Connecticut Party & 1990 & $40.4 \%$ & Did not seek reelection in 1994 \\
Angus King & Maine & Independent & 1994 & $35.4 \%$ & Won a second term in 1998 \\
Angus King & Maine & Independent & 1998 & $58.6 \%$ & Term-limited \\
Jesse Ventura & Minnesota & Reform & 1998 & $37.0 \%$ & Is not seeking reelection in 2002
\end{tabular}

\section{Third Party//ndependent Candidates of Note in 2000}

Following are the limited number of races for federal office in 2000 that were contested by both major parties and a third-party or independent candidate received at least $10 \%$ of the vote. The only winners were two independent House members, Bernie Sanders of Vermont and Virgil H. Goode Jr. of Virginia. Goode is running for reelection this fall as a Republican.

Most of the other races listed below were won easily by the Democratic or Republican candidate, and the vote for independent or third-party candidates did not play a decisive role in the outcome.

However, Republican Rob Simmons ousted veteran Democratic Rep. Sam Gejdenson in Connecticut's 2nd District on the basis of several thousand votes that Simmons picked up on the Independence Party line. Simmons had been endorsed by the third party, and without the votes from that line Republicans would not have picked up the seat in 2000.

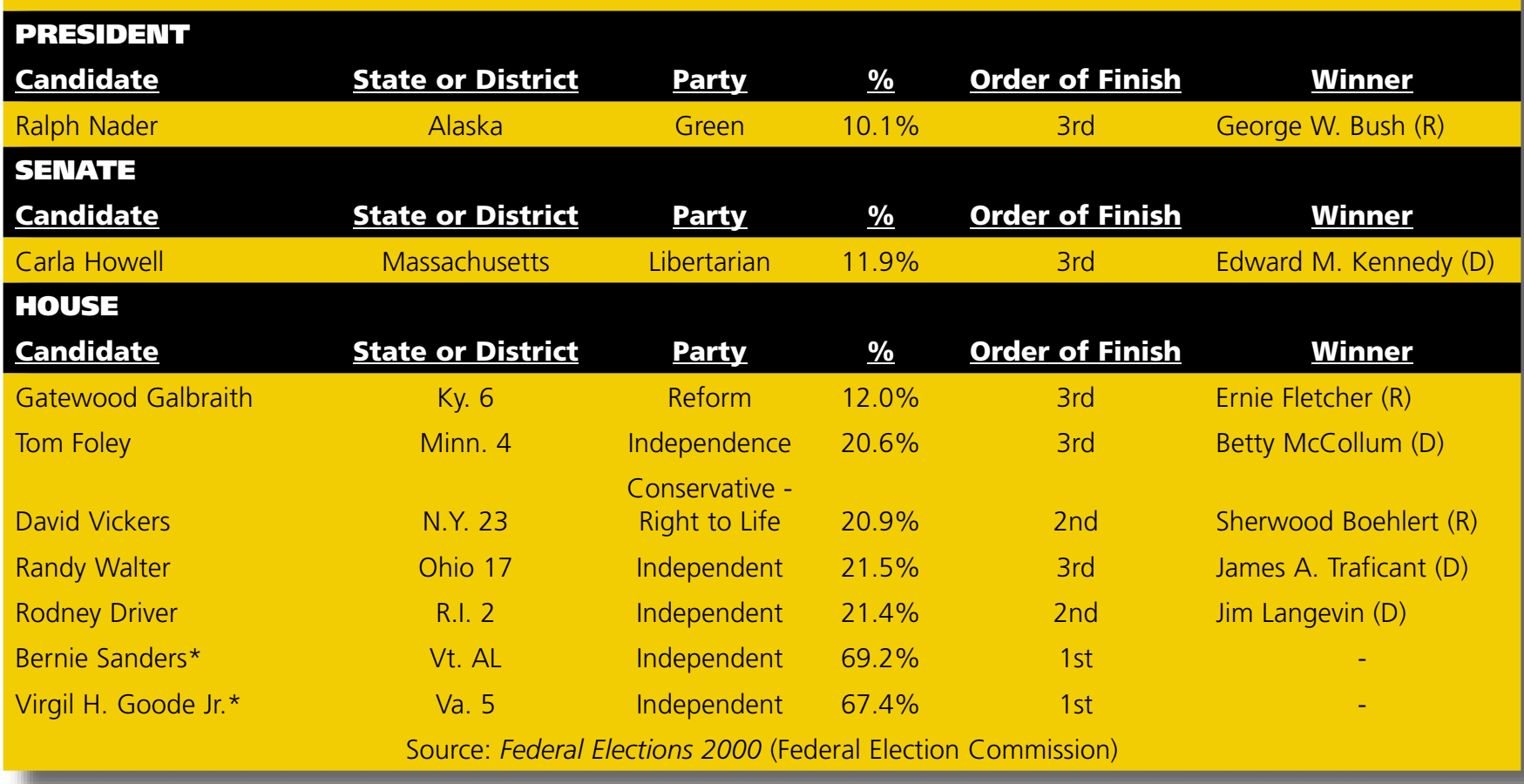




\section{Gubernatorial and Senate Candidates at a Glance}

Dashes in the Senate or gubernatorial columns indicate there is no race for that particular office this year. An asterisk (*) denotes an incumbent. A pound sign (\#) indicates that a recent change in candidates has taken place. Frank Lautenberg has replaced Robert Torricelli as the Democratic Senate candidate in New Jersey. Walter Mondale has replaced the late Paul Wellstone as the Democratic Senate candidate in Minnesota.

Gubernatorial Races

Senate Races

\begin{tabular}{|c|c|c|c|c|c|}
\hline State & Primary & Democrats & Republicans & Democrats & Republicans \\
\hline California & March 5 & Gray Davis* & Bill Simon Jr. & - & - \\
\hline Texas & March 12 & Tony Sanchez & Rick Perry* & Ron Kirk & John Cornyn \\
\hline Illinois & March 19 & Rod Blagojevich & Jim Ryan & Richard J. Durbin* & Jim Durkin \\
\hline Indiana & May 7 & - & - & - & - \\
\hline Ohio & May 7 & Tim Hagan & Bob Taft* & - & - \\
\hline Nebraska & May 14 & Stormy Dean & Mike Johanns* & Charlie A. Matulka & Chuck Hagel* \\
\hline West Virginia & May 14 & - & - & $\begin{array}{c}\text { John D. Rockefeller } \\
\text { IV* }\end{array}$ & Jay Wolfe \\
\hline Arkansas & May 21 & Jimmie Lou Fisher & Mike Huckabee* & Mark Pryor & Tim Hutchinson* \\
\hline Oregon & May 21 & Ted Kulongoski & Kevin Mannix & Bill Bradbury & Gordon H. Smith* \\
\hline Pennsylvania & May 21 & Ed Rendell & Mike Fisher & - & - \\
\hline Idaho & May 28 & Jerry Brady & Dirk Kempthorne* & Alan Blinken & Larry Craig* \\
\hline Kentucky & May 28 & - & - & $\begin{array}{l}\text { Lois Combs } \\
\text { Weinberg }\end{array}$ & Mitch McConnell* \\
\hline Alabama & June 4 & Don Siegelman* & Bob Riley & Susan Parker & Jeff Sessions* \\
\hline lowa & June 4 & Tom Vilsack* & Doug Gross & Tom Harkin* & Greg Ganske \\
\hline Mississippi & June 4 & - & - & Steven Turney & Thad Cochran* \\
\hline Montana & June 4 & - & - & Max Baucus* & Mike Taylor \\
\hline New Jersey & June 4 & - & - & $\begin{array}{c}\text { Frank } \\
\text { Lautenberg\# }\end{array}$ & Douglas Forrester \\
\hline New Mexico & June 4 & Bill Richardson & John Sanchez & Gloria Tristani & Pete Domenici* \\
\hline South Dakota & June 4 & Jim Abbott & Mike Rounds & Tim Johnson* & John Thune \\
\hline Maine & June 11 & John Baldacci & Peter Cianchette & Chellie Pingree & Susan Collins* \\
\hline North Dakota & June 11 & - & - & - & - \\
\hline South Carolina & June 11 & Jim Hodges* & Mark Sanford & Alex Sanders & Lindsey Graham \\
\hline Virginia & June 11 & - & - & (No candidate) & John Warner* \\
\hline Utah & June 25 & - & - & - & - \\
\hline Tennessee & Aug. 1 & Phil Bredesen & Van Hilleary & Bob Clement & Lamar Alexander \\
\hline Kansas & Aug. 6 & $\begin{array}{l}\text { Kathleen } \\
\text { Sebelius }\end{array}$ & $\begin{array}{c}\text { Tim } \\
\text { Shallenburger }\end{array}$ & (No Candidate) & Pat Roberts* \\
\hline Michigan & Aug. 6 & $\begin{array}{l}\text { Jennifer } \\
\text { Granholm }\end{array}$ & Dick Posthumus & Carl Levin* & $\begin{array}{c}\text { Andrew } \\
\text { Raczkowski }\end{array}$ \\
\hline Missouri & Aug. 6 & - & - & Jean Carnahan* & Jim Talent \\
\hline Colorado & Aug. 13 & Rollie Heath & Bill Owens* & Tom Strickland & Wayne Allard* \\
\hline Georgia & Aug. 20 & Roy E. Barnes* & Sonny Perdue & Max Cleland* & Saxby Chambliss \\
\hline
\end{tabular}




\begin{tabular}{|c|c|c|c|c|c|}
\hline State & Primary & Democrats & Republicans & Democrats & Republicans \\
\hline Wyoming & Aug. 20 & Dave Freudenthal & Eli Bebout & Joyce Corcoran & Mike Enzi* \\
\hline Alaska & Aug. 27 & Fran Ulmer & Frank Murkowski & Frank Vondersaar & Ted Stevens* \\
\hline Oklahoma & Aug. 27 & Brad Henry & Steve Largent & David Walters & Jim Inhofe* \\
\hline Nevada & Sept. 3 & Joe Neal & Kenny Guinn* & - & - \\
\hline Delaware & Sept. 7 & - & - & Joe Biden* & Ray Clatworthy \\
\hline Arizona & Sept. 10 & Janet Napolitano & Matt Salmon & - & - \\
\hline Connecticut & Sept. 10 & Bill Curry & John Rowland* & - & - \\
\hline Florida & Sept. 10 & Bill McBride & Jeb Bush* & - & - \\
\hline Maryland & Sept. 10 & $\begin{array}{c}\text { Kathleen Kennedy } \\
\text { Townsend }\end{array}$ & Robert Ehrlich & - & - \\
\hline Minnesota & Sept. 10 & Roger Moe & Tim Pawlenty & Walter Mondale\# & Norm Coleman \\
\hline New Hampshire & Sept. 10 & Mark Fernald & Craig Benson & Jeanne Shaheen & John E. Sununu \\
\hline New York & Sept. 10 & Carl McCall & George Pataki* & - & - \\
\hline North Carolina & Sept. 10 & - & - & Erskine Bowles & Elizabeth Dole \\
\hline Rhode Island & Sept. 10 & Myrth York & Don Carcieri & Jack Reed* & Bob Tingle \\
\hline Vermont & Sept. 10 & Douglas Racine & James Douglas & - & - \\
\hline Wisconsin & Sept. 10 & Jim Doyle & Scott McCallum* & - & - \\
\hline Massachusetts & Sept. 17 & Shannon O'Brien & Mitt Romney & John Kerry* & (No Candidate) \\
\hline Washington & Sept. 17 & - & - & - & - \\
\hline Hawaii & Sept. 21 & Mazie Hirono & Linda Lingle & - & - \\
\hline
\end{tabular}

\section{ELECTION DAY POLL CLOSING TIMES}

Following are poll closing times on Election Day Nov. 5. If a state falls into more than one time zone, the latest closing time is listed. All times are Eastern Standard Time:

7 p.m. --- Ga., Ind., Ky., S.C., Vt., Va.

7:30 p.m. --- N.C., Ohio, W.V.

8 p.m. --- Ala., Conn., Del., Fla., Ill., Kan., Maine, Mass., Md., Miss., Mo., N.H., N.J., Okla., Pa., Tenn.

8:30 p.m. --- Ark.

9 p.m. --- Ariz., Colo., La., Mich., Minn., Neb., N.M., N.Y., N.D., R.I., S.D., Texas, Wis., Wyo.

10 p.m. --- Iowa, Mont., Nev., Utah.

11 p.m. --- Calif., Hawaii, Idaho, Ore., Wash.

1 a.m. --- Alaska. 


\section{State by State: What's Up In 2002}

\begin{tabular}{|c|c|c|c|c|c|c|c|}
\hline & & HOUS: & E SEA & TS & & & \\
\hline & 2002 & & Curre & nt T & otals & & \\
\hline State & Total & Change & $\mathbf{R}$ & D & I & SENATORS & GOVERNORS \\
\hline Alabama & 7 & & 5 & 2 & & Jeff Sessions (R) & Don Siegelman (D) \\
\hline Alaska & 1 & & 1 & & & Ted Stevens (R) & Tony Knowles (D) \\
\hline Arizona & 8 & +2 & 5 & 1 & & & Jane Dee Hull (R) \\
\hline Arkansas & 4 & & 1 & 3 & & Tim Hutchinson (R) & Mike Huckabee (R) \\
\hline California & 53 & +1 & 20 & 32 & & & Gray Davis (D) \\
\hline Colorado & 7 & +1 & 4 & 2 & & Wayne Allard (R) & Bill Owens (R) \\
\hline Connecticut & 5 & -1 & 3 & 3 & & & John G. Rowland (R) \\
\hline Delaware & 1 & & 1 & & & Joseph R. Biden (D) & \\
\hline Florida & 25 & +2 & 15 & 8 & & & Jeb Bush (R) \\
\hline Georgia & 13 & +2 & 8 & 3 & & Max Cleland (D) & Roy E. Barnes (D) \\
\hline Hawaii & 2 & & & 1 & & & Benjamin J. Cayetano (D) \\
\hline Idaho & 2 & & 2 & & & Larry Craig (R) & Dirk Kempthorne (R) \\
\hline Illinois & 19 & -1 & 10 & 10 & & Richard J. Durbin (D) & George H. Ryan (R) \\
\hline Indiana & 9 & -1 & 6 & 4 & & & \\
\hline lowa & 5 & & 4 & 1 & & Tom Harkin (D) & Tom Vilsack (D) \\
\hline Kansas & 4 & & 3 & 1 & & Pat Roberts (R) & Bill Graves (R) \\
\hline Kentucky & 6 & & 5 & 1 & & Mitch McConnell (R) & \\
\hline Louisiana & 7 & & 5 & 2 & & Mary L. Landrieu (D) & \\
\hline Maine & 2 & & & 2 & & Susan M. Collins (R) & Angus King (Ind.) \\
\hline Maryland & 8 & & 4 & 4 & & & Parris N. Glendening (D) \\
\hline Massachusetts & 10 & & & 10 & & John F. Kerry (D) & Jane Swift (R) \\
\hline Michigan & 15 & -1 & 7 & 9 & & Carl Levin (D) & John Engler (R) \\
\hline Minnesota & 8 & & 3 & 5 & & Paul Wellstone (D) & Jesse Ventura (IPM) \\
\hline Mississippi & 4 & -1 & 2 & 3 & & Thad Cochran (R) & \\
\hline Missouri & 9 & & 5 & 4 & & Jean Carnahan (D) & \\
\hline Montana & 1 & & 1 & & & Max Baucus (D) & \\
\hline Nebraska & 3 & & 3 & & & Chuck Hagel (R) & Mike Johanns (R) \\
\hline Nevada & 3 & +1 & 1 & 1 & & & Kenny Guinn (R) \\
\hline New Hampshire & 2 & & 2 & & & Robert C. Smith (R) & Jeanne Shaheen (D) \\
\hline New Jersey & 13 & & 6 & 7 & & Robert G. Torricelli (D) & \\
\hline New Mexico & 3 & & 2 & 1 & & Pete V. Domenici (R) & Gary E. Johnson (R) \\
\hline New York & 29 & -2 & 12 & 19 & & & George E. Pataki (R) \\
\hline North Carolina & 13 & +1 & 7 & 5 & & Jesse Helms (R) & \\
\hline North Dakota & 1 & & & 1 & & & \\
\hline Ohio & 18 & -1 & 11 & 6 & & & Robert A. Taft II (R) \\
\hline Oklahoma & 5 & -1 & 5 & 1 & & James M. Inhofe (R) & Frank Keating (R) \\
\hline Oregon & 5 & & 1 & 4 & & Gordon H. Smith (R) & John Kitzhaber (D) \\
\hline Pennsylvania & 19 & -2 & 11 & 10 & & & Mark Schweiker (R) \\
\hline Rhode Island & 2 & & & 2 & & John F. Reed (D) & Lincoln C. Almond (R) \\
\hline South Carolina & 6 & & 4 & 2 & & Strom Thurmond (R) & James H. Hodges (D) \\
\hline South Dakota & 1 & & 1 & & & Tim Johnson (D) & William J. Janklow (R) \\
\hline Tennessee & 9 & & 5 & 4 & & Fred Thompson (R) & Don Sundquist (R) \\
\hline Texas & 32 & +2 & 13 & 17 & & Phil Gramm (R) & Rick Perry (R) \\
\hline Utah & 3 & & 2 & 1 & & & \\
\hline Vermont & 1 & & & & 1 & & Howard Dean (D) \\
\hline Virginia & 11 & & 8 & 3 & & John W. Warner (R) & \\
\hline Washington & 9 & & 3 & 6 & & & \\
\hline West Virginia & 3 & & 1 & 2 & & John D. Rockefeller IV (D) & \\
\hline Wisconsin & 8 & -1 & 4 & 5 & & & Scott McCallum (R) \\
\hline Wyoming & 1 & & 1 & & & Michael B. Enzi (R) & Jim Geringer (R) \\
\hline THATOTAL & 435 & & 223 & 208 & 1 & $34 \mathrm{Up}(20 \mathrm{R}, 14 \mathrm{D})$ & 36 Up $(23 R, 11 D, 2 I)$ \\
\hline
\end{tabular}

Note: Gov. Jesse Ventura is a member of the Independence Party of Minnesota (IPM). As of Oct. 31, there were three vacant Democratic House seats - two in Ohio and one in Hawaii - which are not included in the totals. 


\section{Subscribe to}

The Rhodes Cook Letter!

Please fill in the information below.

Indicate whether you would prefer the newsletter be sent to you electronically, or in printed form through the mail.

(Please fill in your e-mail address in any case.)

A subscription is $\$ 99$ for six issues. Indicate whether you are enclosing a check now or would prefer to be billed later by mail.

The newsletter is published on a bimonthly basis, with the next issue in December 2002.

Please mail this form and a check (if you are paying now) to "The Rhodes Cook Letter," P.O. Box 574, Annandale, VA. 22003. Thank you.

\section{Name:}

E-Mail Address:

Street Address:

City, State, Zip:

Organization (if applicable):

Phone number (optional):

Type of Payment:

Check Enclosed

payable to "The Rhodes Cook Letter"

Bill My Credit Card

Credit Card Number: Expiration:

Bill Me By Mail

I would like to receive the newsletter:

Electronically

By Mail 